\title{
Adsorption of lead, zinc and cadmium ions from contaminated water onto Peganum harmala seeds as biosorbent
}

\author{
A. A. Zamani • R. Shokri • M. R. Yaftian • \\ A. H. Parizanganeh
}

Received: 19 June 2011/Revised: 25 October 2011 / Accepted: 3 January 2012/ Published online: 4 September 2012

(c) CEERS, IAU 2012

\begin{abstract}
Peganum harmala seeds were assessed as biosorbent for removing $\mathrm{Pb}^{2+}, \mathrm{Zn}^{2+}$ and $\mathrm{Cd}^{2+}$ ions from aqueous solutions. The effects of various parameters such as the aqueous solution $\mathrm{pH}$, the contact time, the initial metal concentration and the amount of adsorbent in the process were investigated. The adsorption efficiencies increased with $\mathrm{pH}$. It was found that about $95 \%$ of lead, $75 \%$ of zinc and $90 \%$ of cadmium ions could be removed from $45 \mathrm{ml}$ of aqueous solution containing $20 \mathrm{mg} \mathrm{l}^{-1}$ of each cation with $2 \mathrm{~g}$ of adsorbent at $\mathrm{pH} 4.5$ after $15 \mathrm{~min}$. The quantitative desorption of cadmium from adsorbent surface was achieved using $10 \mathrm{ml}$ of a $0.5 \mathrm{M}$ nitric acid solution. This condition was attained for lead and zinc ions with $10 \mathrm{ml}$ of $1 \mathrm{M}$ hydrochloric acid solution. Kinetic investigation of the process was performed by considering a pseudo-second-order model. This model predicts the chemisorption mechanism of the process. Langmuir, Freundlich, Temkin and Dubinin-Radushkevich models were tested for describing the equilibrium data. It was found that the Freundlich model describes the experimental data resulting from the adsorption of lead ions. However for cadmium and zinc ions, the adsorption equilibria were interpreted with the Langmuir model.
\end{abstract}

Keywords Heavy metals - Decontamination . Adsorption · Isotherms · Peganum harmala

\footnotetext{
A. A. Zamani · R. Shokri · M. R. Yaftian ( $₫)$.

A. H. Parizanganeh

Department of Chemistry, Faculty of Science,

Zanjan University, Zanjan, Iran

e-mail: yaftian@znu.ac.ir
}

\section{Introduction}

Toxic metals are categorized as non-biodegradable toxic pollutants. They can be accumulated in living tissues and transferred throughout the food chain. This has provoked studies on the elimination of heavy metals from this chain, which is important for the protection of public health.

Lead, zinc and cadmium are among the most used heavy metals in various industries. Lead and cadmium are nonessential and non-beneficial elements to plants and animals. The effects of lead poisoning can vary greatly, depending on the age of the person exposed and the amount of metal. High level of lead in children causes anemia, hypertension, stomach and kidney problems, muscle weakness, brain damage and ultimately death. Even very low levels of this metal can affect a child's mental and physical growth (Lanphear et al. 2005; Lewis 2007). Cadmium has been classified by the US Environmental Protection Agency as a carcinogenic element. Chronic exposure to this metal results in kidney dysfunction and high levels of exposure will result in death (Fenglian and Qi 2011). In contrast, zinc is a trace element that is essential for human health. It is important for the physiological functions of living tissue and regulates many biochemical processes. Despite this, stomach cramps, skin irritations, vomiting, nausea and anemia are diseases due to the presence of too large amounts of zinc in the body (Oyaro et al. 2007).

Many separation methods including chemical precipitation (Esalah and Husein 2008), ion exchange (Kiefer and Höll 2001), reverse osmosis (Bakalár et al. 2009), electroplating (Abo-Ghander et al. 2006), solvent extraction (Zamani et al. 2009) and transport through liquid membranes (Canet et al. 2002; Srisuwan and Thongchai 2002) have been developed and used for removal of heavy metal ions from various water samples. It is noteworthy that the use of these methods are often limited due to high cost, 
high reagent and energy requirements, incomplete metal removal and/or production of waste products that themselves require further disposal or treatment.

Surface adsorption is known to be an effective process for decontamination of aqueous samples from heavy metals. A large number of cheap and abundantly natural materials such as mineral rocks, agricultural waste or industrial byproducts have been used as adsorbent (Babel and Kurniawan 2003; Bailey et al. 1999; Igwe and Abia 2006). Waste tea, sugar beet pulp, spent grain, coconut shell, coconut husk, sago waste, wood waste, rice husk, poultry feathers and chitosan are among the efficacious biosorbents for heavy metal removal (Abdel-Ghani et al. 2007; Dela Rosa et al. 2008; Mohan and Pittman 2007; Wan et al. 2010, 2011; Wan Ngah and Hanafiah 2008).

Peganum harmala seed (PHS) is a reputed drug of the Indian system of medicine. The genus Peganum (Peganaceae) is present in flora as " $P$. harmala L." (wild rue) and " $P$. nigellastrum Bge" species. PHS contains several compounds including harmine, harmaline, vasicine and vasicinone (Agedilova et al. 2006; Pulpati et al. 2006); therefore, they can be considered as potential candidates for adsorption of heavy metal ions.

Although there are a great number of studies on the application of biosorbents for removal of heavy metals (Mehrasbi et al. 2009; Pimentel et al. 2007; Souag et al. 2009; Sud et al. 2008; Zvinowanda et al. 2010), to the best of our knowledge, there is no report on the application of $P$. harmala seeds for such purpose. Following the studies on separation, preconcentration and determination of heavy metals (Hami et al. 2010; Parinejad and Yaftian 2007; Yaftian et al. 2005, 2007), this work has been performed from October 2010 to October 2011, in the Phase Equilibria Research Laboratory of University of Zanjan-Iran, to describe the abilities and properties of $P$. harmala, as a biosorbent, for removal of lead, zinc and cadmium ions from aqueous solutions. The effect of the parameters influencing the process such as the aqueous solution $\mathrm{pH}$, the initial metal concentration, the amount of sorbent and the contact time are investigated and discussed. The adsorption isotherms and kinetics of the process are studied.

\section{Materials and methods}

Chemicals

All chemicals used were analytical grade reagents (Merck). A stock solution of ions $\left(1,000 \mathrm{mg} \mathrm{l}^{-1}\right)$ was prepared by dissolving a suitable quantity of the corresponding nitrate salt in deionized water. This solution was standardized by complex formationtitration using a standard EDTA solution (Dean 1995). All working solutions were prepared by diluting the stock solution. Nitric acid and sodium hydroxide solutions were used for $\mathrm{pH}$ adjustments.

Adsorbent preparation and characterization

The natural $P$. harmala seeds were purchased from the Zanjan market and were washed three times with distilled water and finally with deionized water. The seeds were dried in an oven $\left(60^{\circ} \mathrm{C}\right)$ for $24 \mathrm{~h}$ before using in the experiments. The IR spectrum was recorded by using a Nicolet iS10 FT-IR spectrometer. Thermofinnigan CHN analyzer flash EA 1112 was used for elemental analysis of the biosorbent (found: C, 51.31; H, 7.11; N, 4.64; S, 0.12; O, $36.81 \%$ ). SEM photographs were taken with MIRA TESCAN Scanning Microscope to examine the morphology and surface structure of the adsorbents at the required magnification at room temperature. The SEM images of the PHS are shown in Fig. 1. As shown in the SEM micrograph, the PHS have rough and porous surface. This surface property should be considered as a factor providing an increase in the total adsorption surface.

\section{Adsorption experiments}

The experiments were carried out by mixing $1 \mathrm{~g}$ of sorbent with $45 \mathrm{ml}$ of aqueous solution containing lead, zinc and cadmium ions for $15 \mathrm{~min}$. An efficient mixing of the phases was achieved using a mechanical stirrer (Heidolph 2000) at 1,000 rpm. Aliquots were taken at specific time intervals and the metal concentration in the solution was measured by flame atomic absorption spectroscopy (Varian 220 AA). The $\mathrm{pH}$ adjustments were performed using a Metrohm digital $\mathrm{pH}$ meter (model 780) equipped with a combined glass electrode. The amount of adsorbed ions and the corresponding uptake percentage were calculated using Eqs. 1 and 2:

$q_{t}=\frac{\left(C_{0}-C_{t}\right) V}{W}$

Uptake percentage $=\frac{\left(C_{0}-C_{t}\right)}{C_{0}} \times 100$

where " $q_{t}$ " is the amount of ion adsorbed $\left(\mathrm{mg} \mathrm{g}^{-1}\right.$ of sorbent) at time " $t$ ", " $V$ " is the volume of sample solution (1), " $W$ " shows the weight of sorbent $(\mathrm{g})$, and " $C_{0}$ " and " $C_{t}$ " are the metal concentrations in aqueous solution $\left(\mathrm{mg} \mathrm{l}^{-1}\right)$ at the initial and at time " $t$ ", respectively. 

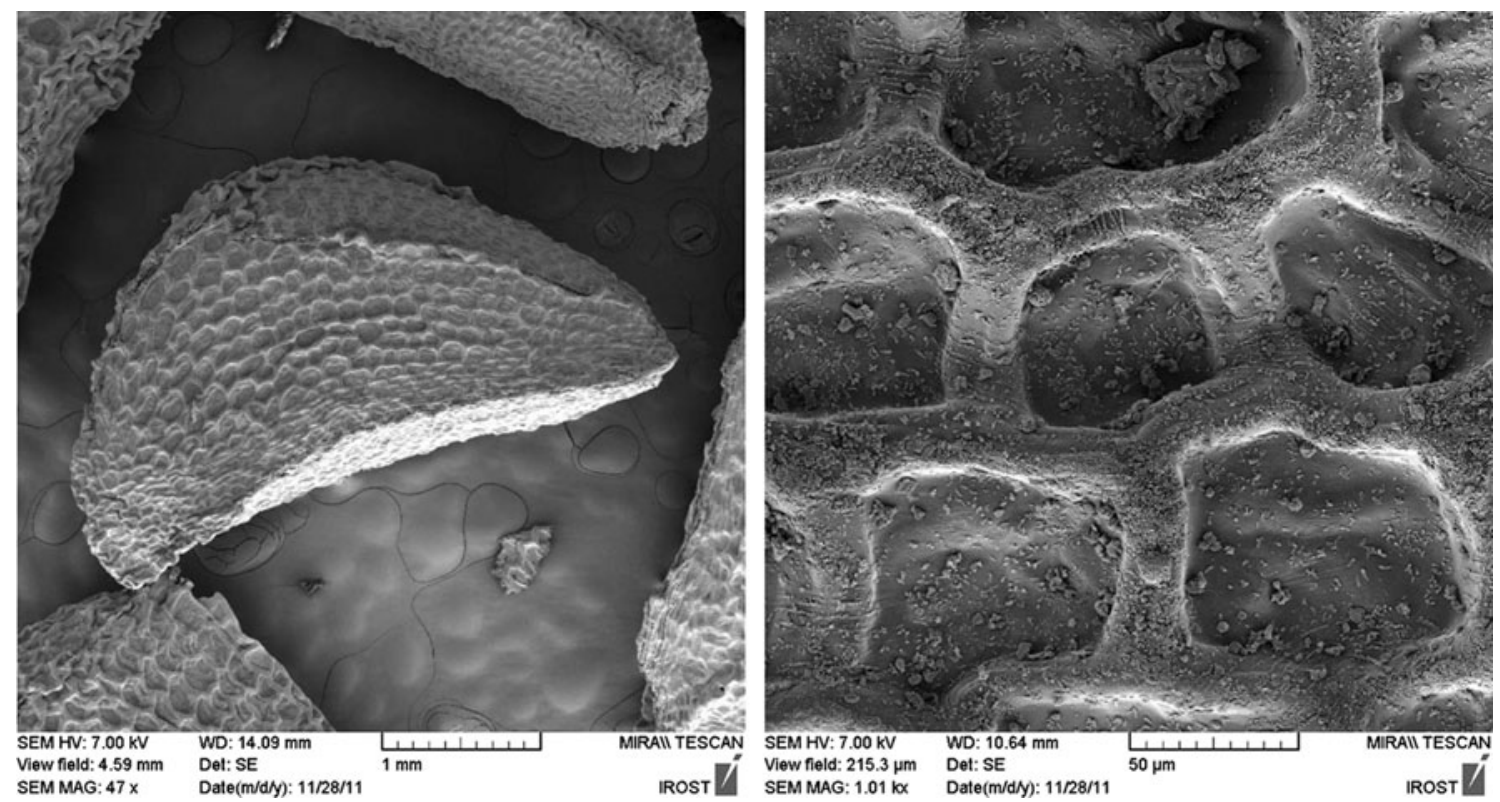

Fig. 1 Scanning electron micrograph (SEM) of dry Peganum harmala seeds

\section{Results and discussion}

IR characterization of the adsorbent

To gain a better insight into the functional groups available on the surface of the investigated adsorbent, the FT-IR spectrum of the sorbent was recorded (Fig. 2). This spectrum shows four intense bands at 3,448, 2,926, 1,653 and $1,385 \mathrm{~cm}^{-1}$. The band at $3,448 \mathrm{~cm}^{-1}$ is attributed to the surface $\mathrm{OH}$ and $\mathrm{NH}$ stretches. The bands at 2,926 were assigned to $\mathrm{C}-\mathrm{H}$ stretches of methylene groups on the surface. The bands found at around $1,653 \mathrm{~cm}^{-1}$ can be assigned to $\mathrm{C}=\mathrm{C}$ or $\mathrm{C}=\mathrm{N}$ stretching frequencies. Weak peak observed at 2,584 and $1,385 \mathrm{~cm}^{-1}$ can be attributed to the $\mathrm{C}-\mathrm{S}$ and $\mathrm{C}-\mathrm{O}$ groups.

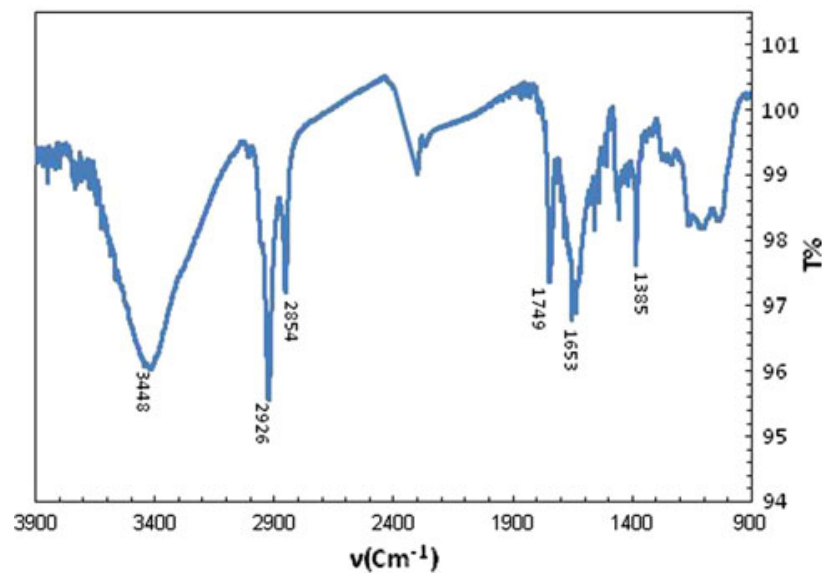

Fig. 2 FT-IR spectrum of Peganum harmala seeds

\section{Effect of $\mathrm{pH}$}

The $\mathrm{pH}$ of sample solutions plays an important role in the adsorption process. This parameter influences the solution chemistry of heavy metals and also strongly affects the ability of biosorbents (Sud et al. 2008). Figure 3 shows the effect of $\mathrm{pH}$ on the adsorption of $\mathrm{Pb}^{2+}, \mathrm{Zn}^{2+}$ and $\mathrm{Cd}^{2+}$ ions by PHS at $20^{\circ} \mathrm{C}$. It is seen that the metal adsorption enhances with $\mathrm{pH}$ values; to ensure the solubility of metal ions, experiments were carried out at $\mathrm{pH}<6$. This can be described by considering the competition between $\mathrm{H}^{+}$ions and metal ions for adsorbing on the surface of the adsorbent at low $\mathrm{pH}$ values. In fact, the $\mathrm{pH}$ dependency of the process can be described by considering the deprotonation of the protonated amine groups at lower $\mathrm{pH}$ values and the ionization of hydroxyl groups at higher $\mathrm{pHs}$.

There is a critical $\mathrm{pH}$ range for any heavy metal ion (often 2 units wide), where the metal uptake efficiency increases from a very low level to a maximum value. This $\mathrm{pH}$ value is commonly called "adsorption edge" (Casagrande et al. 2009; Skwarek et al. 2008). In the present work, this $\mathrm{pH}$ was found to be $2-4$. In the $\mathrm{pH}$ range $4-6$, the adsorption was independent of the $\mathrm{pH}$ variation. It should be noted that for the adsorption process, the adsorption edge increases with the initial ion concentration.

Time dependency of the adsorption process

The adsorption of lead, zinc and cadmium ions at different contact time was studied by keeping all other experimental conditions constant (Fig. 4). Adsorption increases by 

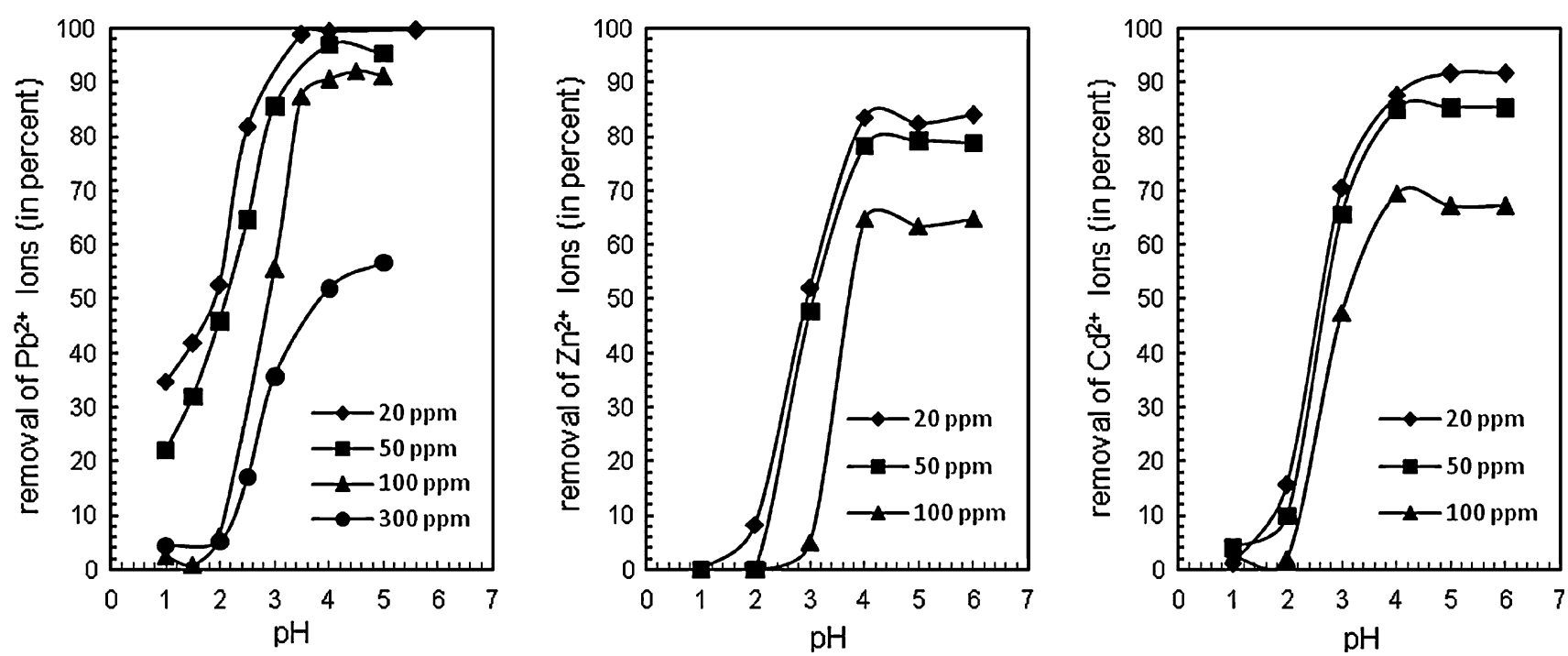

Fig. 3 Uptake of lead, zinc and cadmium ions (in various initial concentrations) by PHS as a function of aqueous phase pH. Experimental conditions: $45 \mathrm{ml}$ sample solution, $1 \mathrm{~g}$ of the sorbent, mixing time $30 \mathrm{~min}$, stirring 1,000 rpm, temperature $20{ }^{\circ} \mathrm{C}$

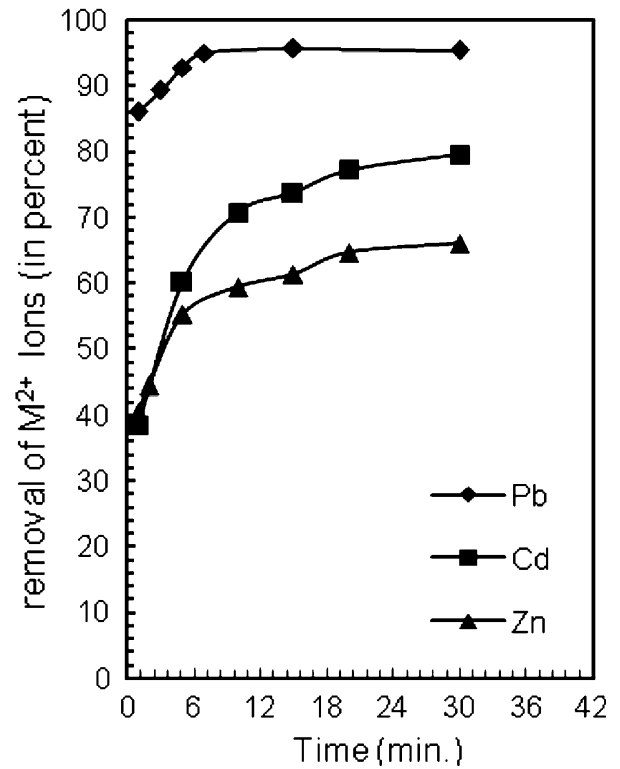

Fig. 4 Uptake of lead (filled diamond), zinc (filled triangle) and cadmium (filled square) ions by PHS as a function of time. Experimental conditions: $45 \mathrm{ml}$ sample solution, initial ion concentration $20 \mathrm{mg} \mathrm{l}^{-1}, 0.8 \mathrm{~g}$ of the sorbent, $\mathrm{pH}=4.5$, stirring 1,000 rpm, temperature $20{ }^{\circ} \mathrm{C}$

increasing contact time and the maximum adsorption takes place after $15 \mathrm{~min}$. The invariant sorption beyond this time can be explained by considering the formation of a monolayer of adsorbed ions.

\section{Kinetics of the process}

The plot of metal uptake as a function of time was smooth and continuous leading to saturation (Fig. 4).
To investigate the controlling mechanism of the adsorption processes' power function, simple Elovich, pseudo-firstorder and pseudo-second-order kinetics were applied to the experimental data (Ho and Ofomaja 2006; Jiang et al. 2007; Vadivelan and Kumar 2005). The power function equation is an empirical model that describes the relation between the mass of the sorbate per unit mass of the adsorbent and time " $t$ ":

$\log q_{t}=\log k_{p}+v \log t$

where " $t$ " is the contact time (min) and " $q_{t}$ " is the quantity of adsorbed ions on the surface of the sorbent $\left(\mathrm{mg} \mathrm{g}^{-1}\right)$ at time " $t$ ". In this equation " $k_{p}$ " $\left(\mathrm{mg} \mathrm{g}^{-1} \min ^{-1}\right)$ and " $v$ " are adjustment parameters.

The simple Elovich model describes the kinetics of the chemisorption process, which is given as:

$q_{t}=a+2.303 b \log t$.

The parameter " $a$ " $\left(\mathrm{mg} \mathrm{g}^{-1} \min ^{-1}\right)$ represents the rate of chemisorption at zero coverage, and the parameter " $b$ " $\left(\mathrm{g} \mathrm{mg}^{-1}\right)$ is the desorption constant that is related to the extent of surface coverage and the activation energy for the adsorption. These parameters are both constant.

The pseudo-first-order kinetics can be expressed by Eq. 5:

$\log \left(q_{e}-q_{t}\right)=\log q_{e}-\frac{k_{1} t}{2.303}$

where " $q_{e}$ " is the quantity of adsorbed ions on the surface of the sorbent $\left(\mathrm{mg} \mathrm{g}^{-1}\right)$ at equilibrium time. In this equation, " $k_{1}$ " denotes the pseudo-first-order rate constant $\left(\mathrm{min}^{-1}\right)$.

A mathematical expression of the pseudo-second-order kinetic model is shown as follows: 
Table 1 Kinetic model parameters for lead, zinc and cadmium ions adsorption on PHS

\begin{tabular}{|c|c|c|c|c|c|c|c|c|c|c|c|c|c|c|}
\hline \multirow[t]{2}{*}{$\mathrm{M}^{2+}$} & \multirow{2}{*}{$\begin{array}{l}\text { Concentration } \\
(\mathrm{ppm})\end{array}$} & \multicolumn{3}{|c|}{ Power function equation } & \multicolumn{3}{|c|}{ Simple Elovich } & \multicolumn{2}{|c|}{ Pseudo-first order } & \multicolumn{5}{|c|}{ Pseudo-second order } \\
\hline & & $k_{\mathrm{p}}$ & $v$ & $R^{2}$ & $a$ & $b$ & $R^{2}$ & $k_{1}$ & $R^{2}$ & $k_{2}$ & $h_{0}$ & $q_{\exp }$ & $q_{\mathrm{e}}$ & $R^{2}$ \\
\hline \multirow[t]{3}{*}{$\mathrm{Pb}^{2+}$} & 20 & 0.770 & 0.033 & 0.849 & 0.588 & 0.0199 & 0.851 & 0.079 & 0.703 & 11.764 & 4.920 & 0.644 & 0.648 & 1.000 \\
\hline & 50 & 0.012 & 0.048 & 0.744 & 1.742 & 0.089 & 0.755 & 0.086 & 0.618 & 3.360 & 13.310 & 1.982 & 1.990 & 1.000 \\
\hline & 100 & 0.221 & 0.055 & 0.870 & 2.815 & 0.171 & 0.874 & 0.099 & 0.706 & 1.030 & 11.570 & 3.316 & 3.350 & 0.999 \\
\hline \multirow[t]{3}{*}{$\mathrm{Zn}^{2+}$} & 20 & 2.576 & 0.122 & 0.925 & 0.381 & 0.059 & 0.917 & 1.276 & 0.930 & 1.276 & 0.470 & 0.593 & 0.607 & 0.994 \\
\hline & 50 & 1.213 & 0.125 & 0.697 & 0.830 & 0.122 & 0.677 & 12.956 & 0.999 & 12.959 & 17.240 & 1.116 & 1.148 & 0.996 \\
\hline & 100 & 1.258 & 0.164 & 0.737 & 1.285 & 0.250 & 0.800 & 0.582 & 0.879 & 0.581 & 2.542 & 2.045 & 2.088 & 0.999 \\
\hline \multirow[t]{3}{*}{$\mathrm{Cd}^{2+}$} & 20 & 0.372 & 0.220 & 0.966 & 0.366 & 0.115 & 0.988 & 0.082 & 0.946 & 0.783 & 0.465 & 0.736 & 0.771 & 0.999 \\
\hline & 50 & 5.667 & 0.291 & 0.826 & 0.268 & 0.109 & 0.837 & 0.075 & 0.547 & 1.512 & 0.555 & 0.585 & 0.606 & 0.992 \\
\hline & 100 & 1.459 & 0.399 & 0.908 & 0.065 & 0.048 & 0.964 & 0.069 & 0.911 & 1.227 & 0.073 & 0.225 & 0.244 & 0.994 \\
\hline
\end{tabular}

$\frac{t}{q_{t}}=\frac{1}{k_{2} q_{e}^{2}}+\frac{t}{q_{e}}$

In this equation, " $k_{2}$ " denotes the pseudo-second-order rate constant (in $\mathrm{g} \mathrm{mg}^{-1} \mathrm{~min}^{-1}$ ). In this model, the initial rate of sorption can be evaluated as $q_{t} / t$ approaches to zero:

$h_{0}=k_{2} q_{e}^{2}$

where " $h_{0}$ " is the initial rate of sorption $\left(\mathrm{mg} \mathrm{g}^{-1} \mathrm{~min}^{-1}\right)$.

Table 1 contains the kinetic parameters evaluated based on the described model for the adsorption of lead, zinc and cadmium ions onto PHS. Considering the values of correlation coefficients, it can be concluded that the power function, simple Elovich, pseudo-first-order kinetic model does not adequately describe the adsorption results. However, the pseudo-second-order kinetic model provided an impressive and comparable correlation for the adsorption of ions in contrast to the other models. The comparison of the evaluated adsorption capacity considering the pseudosecond-order equation $\left(q_{e}\right)$ and that found experimentally $\left(q_{\exp }\right)$ confirms the validity of the proposed model.

Effect of adsorbent amount

The effect of adsorbent quantity on the removal of ions was studied by using 0.1-3 g of adsorbent (Fig. 5). It was found that an amount of $0.5 \mathrm{~g}$ of PHS can quantitatively remove lead ions from $45 \mathrm{ml}$ of contaminated lead solution (20 mg $\mathrm{l}^{-1}$ ). However, a quantity higher than $1.5 \mathrm{~g}$ of the adsorbent is able to uptake about 90 and $75 \%$ of cadmium and zinc ions, respectively.

Ionic strength study

Figure 6 shows the influence of the ionic strength on the capacity of adsorption. It was tested by the addition of

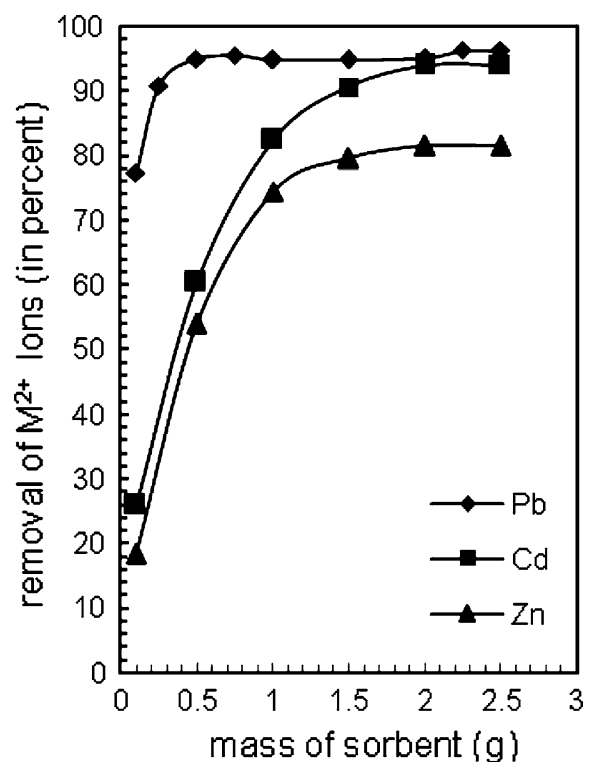

Fig. 5 Uptake of lead (filled diamond), zinc (filled triangle) and cadmium (filled square) ions as a function of the amount of PHS. Experimental conditions: $45 \mathrm{ml}$ sample solution, initial ion concentration $20 \mathrm{mg}^{-1}, \mathrm{pH}=4.5$, stirring $1,000 \mathrm{rpm}$, mixing time $15 \mathrm{~min}$, temperature $20^{\circ} \mathrm{C}$

sodium nitrate and potassium nitrate $(0.1,0.5,1,2 \mathrm{M})$ to the solution. An increase in ionic strength diminishes the adsorption of all the studied ions. The ionic strength can be explained by considering the electrostatic attraction of the salt cations, which causes the surface of the adsorbent to be unfavorable toward target ions, resulting in a decrease in the removal of metal ions.

Desorption studies

Recovery of adsorbed material is important from the metal ion recycling point of view. As the quantitative desorption 


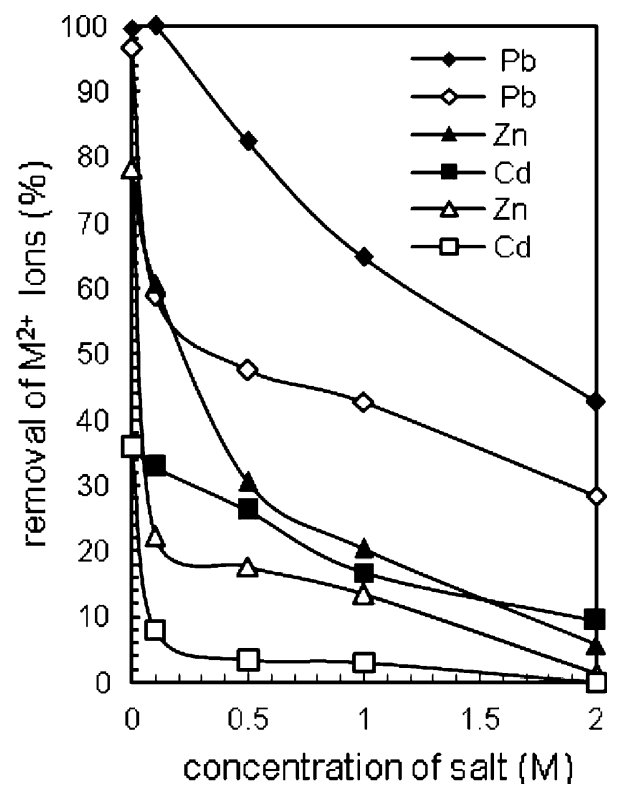

Fig. 6 Effect of ionic strength (using $\mathrm{KNO}_{3}$ and $\mathrm{NaNO}_{3}$ salts, filled and empty symbols, respectively) on the removal of lead (filled diamond), zinc (filled diamond) and cadmium (filled square) ions from aqueous solution by PHS. Experimental conditions: $45 \mathrm{ml}$ sample solution, initial ion concentration $50 \mathrm{mg}^{-1}, \mathrm{pH}=4.5,1 \mathrm{~g}$ of the sorbent, stirring $1,000 \mathrm{rpm}$, mixing time $15 \mathrm{~min}$, temperature $20{ }^{\circ} \mathrm{C}$

of the adsorbed metal ions on the sorbent by distilled water was not successful, hydrochloric, nitric and sulfuric acids were tested to this end. A series of experiments was carried out by adding the PHS loaded with the metal ions to $10 \mathrm{ml}$ of diluted acid solutions and stirring the solutions at $100 \mathrm{rpm}$ for $30 \mathrm{~min}$.

As shown in Fig. 7, $\mathrm{HCl}$ solution (1 M) presents higher desorption capacity toward zinc and lead ions, while $\mathrm{HNO}_{3}$ solution $(0.5 \mathrm{M})$ desorbs quantitatively cadmium ions from the sorbent. More than $98 \%$ of all the studied ions were stripped under the selected conditions.

\section{Sorption isotherms}

Adsorption isotherms are important to describe how solutes interact with adsorbents and to design adsorption systems for practical or technological use. Moreover, they are useful for describing the adsorption capacity to facilitate evaluation of the feasibility of the process for selection of an appropriate adsorbent, and for preliminary determination of the optimum amount of adsorbent (Mehrasbi et al. 2009).

The Langmuir, Freundlich, Temkin and Dubinin-Radushkevich (D-R) models (Nameni et al. 2008) were used to describe the sorption isotherms. The Langmuir model assumes that the uptake of metal ions occurs on a homogenous surface by monolayer adsorption without any interaction between the adsorbed ions. The Freundlich model considers that the uptake of metal ions occurs on a heterogeneous surface by multilayer adsorption. Temkin isotherm assumes that fall in heat of sorption is linear rather than logarithmic, as given in the Freundlich

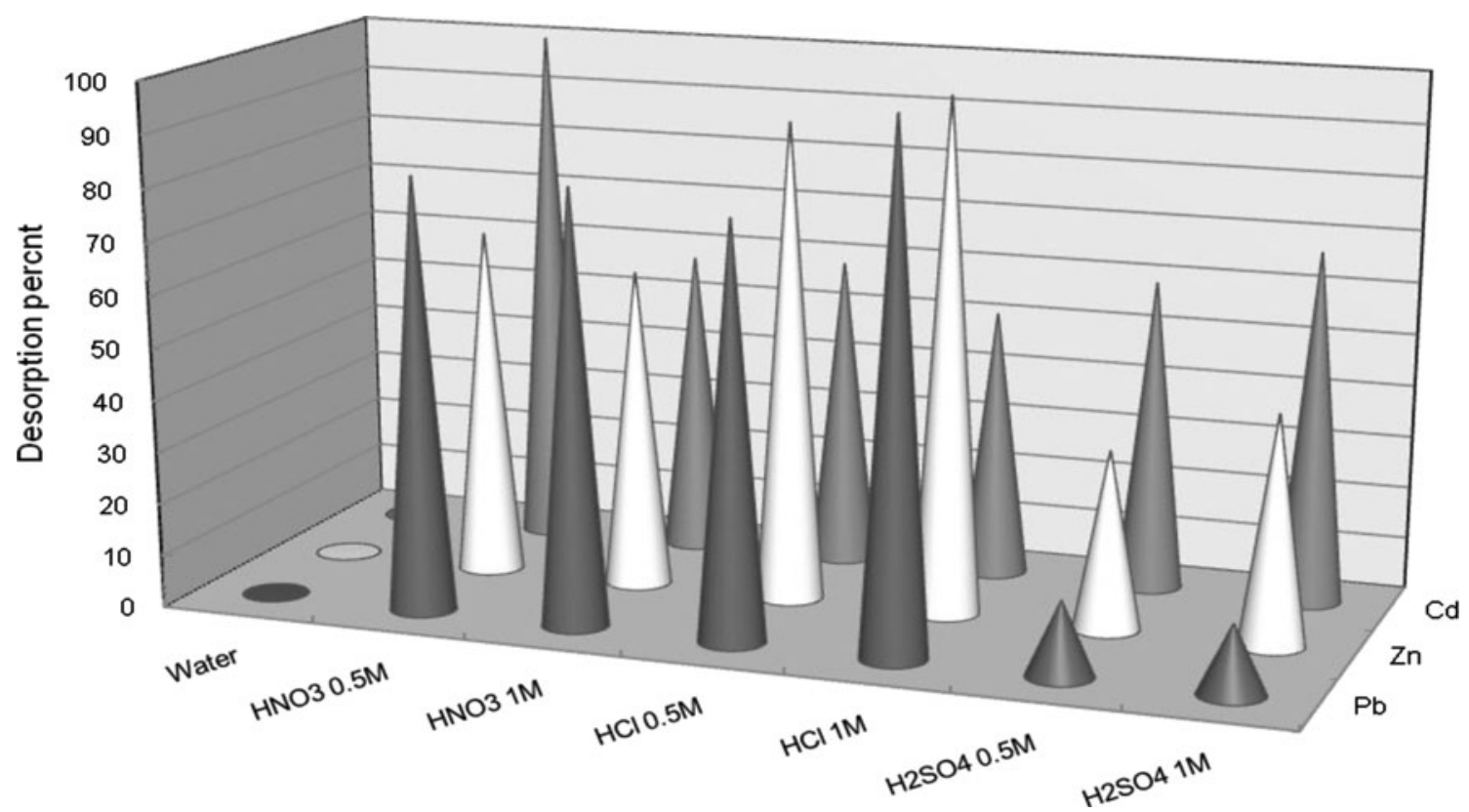

Fig. 7 Desorption of lead, zinc and cadmium ions on PHS with diluted acids and distilled water. Experimental conditions: $45 \mathrm{ml}$ sample solution, initial ion concentration $50 \mathrm{mg} \mathrm{l}^{-1}, \mathrm{pH}=4.5,1 \mathrm{~g}$ of the sorbent, stirring $1,000 \mathrm{rpm}$, mixing time $15 \mathrm{~min}$, temperature $20{ }^{\circ} \mathrm{C}$ 
equation. Due to sorbate/sorbent interaction, the heat of sorption of all the molecules in the adsorbed layer would decrease linearly with coverage. Dubinin-Radushkevich isotherm, like Freundlich model, assumes a heterogeneous surface.

The Langmuir equation (Eq. 8) was applied to the sorption equilibria at different adsorbent doses:

$q_{e}=\frac{b Q_{\max } C_{e}}{1+b C_{e}}$.

Its linear form is

$\frac{C_{e}}{q_{e}}=\frac{1}{Q_{\max } b}+\frac{C_{e}}{Q_{\max }}$

where " $C_{e}$ " is the concentration of the metal ion solution at equilibrium ( $\left.\mathrm{mg}^{-1}\right)$, " $q_{e}$ " the amount of metal sorbed at equilibrium $\left(\mathrm{mg} \mathrm{g}^{-1}\right)$, " $Q_{\max } "$ the maximum sorption capacity of metal-PHS system and " $b$ " is the constant related to binding energy of the sorption system. Furthermore, the favorability of adsorption was tested using a dimensionless constant called separation factor $\left(R_{L}\right)$ (Vadivelan and Kumar 2005), which is an essential feature of the Langmuir isotherm:

$R_{L}=\frac{1}{1+b C_{0}}$

where " $C_{0}$ " is the initial concentration of the metal in solution $\left(\mathrm{mg} \mathrm{l}^{-1}\right)$. The values of $R_{L}$ ranging between 0 and 1 confirm the feasibility of sorption onto biosorbents.

The equation describing the Freundlich model is:

$q_{e}=K C_{e}^{n}$.

Its logarithmic form was applied to the sorption equilibria at different adsorbent doses

$\log q_{e}=\frac{1}{n} \log C_{e}+\log K$

where " $K$ " and " $n$ " are called Freundlich constants. They are relative indicators of adsorption capacity and adsorption intensity, respectively. A favorable adsorption condition is achieved when $n>1$. form:

Temkin isotherm has been applied in the following

$q_{e}=\frac{R T}{b} \ln \left(a C_{e}\right)$

where " $b$ " is the Temkin constant related to the heat of sorption $(\mathrm{kJ} / \mathrm{mol}), \quad R$ denotes the gas constant $\left(0.0083 \mathrm{~kJ} \mathrm{~K}^{-1} \mathrm{~mol}^{-1}\right)$, " $a$ " is the Temkin isotherm constant $(1 / \mathrm{g})$ and $T$ shows the absolute temperature $(\mathrm{K})$.

The equation describing the Dubinin-Radudshkevich $(\mathrm{D}-\mathrm{R})$ model is:
$q_{e}=q_{D} \exp \left(-B_{D} E_{D}^{2}\right)$,

In which $E_{D}$ (polanyi potential) is calculated by:

$E_{D}=R T \ln \left(1+\frac{1}{C_{e}}\right)$

where " $q_{D}$ " is the adsorption capacity of sorbent $\left(\mathrm{mg} \mathrm{g}^{-1}\right)$, " $q_{e}$ " is the amount of metal adsorbed at equilibrium time $\left(\mathrm{mg} \mathrm{g}^{-1}\right)$ and " $B_{D}$ " denotes a constant related to the absorption energy $\left(\mathrm{mol}^{2} \mathrm{~kJ}^{-2}\right)$. The mean energy of sorption can be calculated as follows:

$E=\frac{1}{\sqrt{2 B_{D}}}$.

The magnitude of " $E$ " allows suggesting the mechanism of the adsorption process (Santhi et al. 2009). In fact, when " $E$ " is in the range $8-16 \mathrm{~kJ} \mathrm{~mol}^{-1}$, an ion exchange mechanism can be envisaged for the process. The dominant mechanism is physisorption with respect to chemisorptions and ion exchange mechanisms, when " $E$ " is lower than $8 \mathrm{~kJ} \mathrm{~mol}^{-1}$. The corresponding sorption isotherm constants and correlation coefficients are presented in Table 2. The obtained correlation coefficients reveal that the adsorption process is better described by Langmuir and Freundlich models. However, the adsorption data of lead ions on PHS is better described by the Freundlich isotherm than the Langmuir isotherm. It is reverse for the adsorption of zinc and cadmium ions. In fact, the isotherms for zinc and cadmium adsorption are better defined by the Langmuir model. Based on the $\mathrm{R}_{\mathrm{L}}$ values, the adsorption process is categorized (Vadivelan and Kumar 2005) as unfavorable $(>1)$, linear $(=1)$, favorable $\left(0<R_{L}<1\right)$ and irreversible $(=0)$. Thus, the proposed method can be considered as a favorable uptake process for the studied metal ions (Table 2).

\section{Application of the proposed method}

To assess the applicability of the proposed method, it was applied for the removal of lead, cadmium and zinc from three preliminarily treated effluents from lead and zinc production industries in the Zanjan Province, Iran. Table 3 shows some characteristics of these samples.

It is noteworthy that the tested real samples contained low level of target metal ions; thus, this investigation was performed by the addition of a defined quantity of the target metal ions in the two first samples. The results are based on four replicate experiments and are regrouped in Table 4. As seen from the table, the proposed method 
Table 2 Sorption isotherm parameters for lead, zinc and cadmium ions adsorption on PHS

\begin{tabular}{|c|c|c|c|c|c|c|c|c|c|c|c|c|c|c|}
\hline \multirow[t]{2}{*}{$\mathrm{M}^{2+}$} & \multicolumn{4}{|c|}{ Langmuir } & \multicolumn{3}{|c|}{ Freundlich } & \multicolumn{3}{|c|}{ Temkin } & \multicolumn{4}{|c|}{ Dubinin-Radushkevich } \\
\hline & $Q_{\max }$ & $B$ & $R_{\mathrm{L}}$ & $R^{2}$ & $k_{\mathrm{f}}$ & $n$ & $R^{2}$ & $a$ & $b$ & $R^{2}$ & $q_{\mathrm{D}}$ & $B_{\mathrm{D}}$ & $E$ & $R^{2}$ \\
\hline $\mathrm{Pb}^{2+}$ & 90.091 & 0.012 & 0.568 & 0.991 & 1.094 & 0.910 & 0.997 & 0.755 & 0.267 & 0.881 & 13.236 & 1.074 & 0.682 & 0.749 \\
\hline $\mathrm{Zn}^{2+}$ & 10.460 & 0.006 & 0.775 & 0.946 & 0.067 & 1.036 & 0.911 & 0.139 & 1.841 & 0.782 & 1.994 & 24.27 & 0.144 & 0.763 \\
\hline $\mathrm{Cd}^{2+}$ & 1.551 & 0.351 & 0.117 & 0.877 & 5.378 & 1.840 & 0.850 & 1.318 & 3.946 & 0.678 & 1.267 & 0.482 & 1.018 & 0.559 \\
\hline
\end{tabular}

$Q_{0}\left(\mathrm{mg} \mathrm{g}^{-1}\right), b\left(1 \mathrm{mg}^{-1}\right), k_{\mathrm{f}}\left(\mathrm{mg} \mathrm{g}^{-1}\right), a\left(\mathrm{lg}^{-1}\right), b\left(\mathrm{~kJ} \mathrm{~mol}^{-1}\right), q_{\mathrm{D}}\left(\mathrm{mg} \mathrm{g}^{-1}\right), B_{\mathrm{D}}\left(\mathrm{mol}^{2} \mathrm{~kJ}^{2}\right), E\left(\mathrm{~kJ}^{2} \mathrm{~mol}^{-2}\right)$

Table 3 Some physical and chemical characteristic of the examined real samples

\begin{tabular}{|c|c|c|c|c|c|c|c|c|c|}
\hline Sample & $\mathrm{pH}$ & $\begin{array}{l}\text { TDS } \\
\left(\mathrm{mg}^{-1}\right)\end{array}$ & 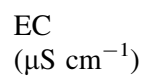 & $\begin{array}{l}\mathrm{Pb}^{2+} \\
\left(\mathrm{mg} \mathrm{l}^{-1}\right)\end{array}$ & $\begin{array}{l}\mathrm{Cd}^{2+} \\
\left(\mathrm{mg} \mathrm{l}^{-1}\right)\end{array}$ & $\begin{array}{l}\mathrm{Zn}^{2+} \\
\left(\mathrm{mg} \mathrm{l}^{-1}\right)\end{array}$ & $\begin{array}{l}\mathrm{Ni}^{2+} \\
\left(\mathrm{mg} \mathrm{l}^{-1}\right)\end{array}$ & $\begin{array}{l}\mathrm{Cu}^{2+} \\
\left(\mathrm{mg} \mathrm{1}^{-1}\right)\end{array}$ & $\begin{array}{l}\mathrm{Co}^{2+} \\
\left(\mathrm{mg} \mathrm{l}^{-1}\right)\end{array}$ \\
\hline 1 & 6.5 & 158 & 316 & 5.5 & 5 & 10.1 & ND & ND & ND \\
\hline 2 & 7.0 & 288 & 577 & ND & ND & 0.3 & ND & ND & ND \\
\hline 3 & 5.5 & 320 & 654 & 15.2 & ND & 7.1 & ND & ND & ND \\
\hline
\end{tabular}

$N D$ not detected

Table 4 Removal of lead, zinc and cadmium ions from real samples with adsorption on PHS

$N D$ not detected

\begin{tabular}{|c|c|c|c|c|c|}
\hline \multirow[t]{2}{*}{ Sample } & \multicolumn{4}{|c|}{ Concentration of lead, zinc and cadmium ions $\left(\mathrm{mg} \mathrm{l}^{-1}\right)$} & \multirow{2}{*}{$\begin{array}{l}\text { Uptake percentage } \\
(< \pm 0.5 \%)\end{array}$} \\
\hline & Metal ion & Added ion & Before removal & After removal & \\
\hline \multirow[t]{3}{*}{1} & Lead & 20.0 & 26.4 & 0.81 & 96.9 \\
\hline & Cadmium & 20.0 & 25.8 & 3.99 & 84.5 \\
\hline & Zinc & 20.0 & 29.9 & 6.00 & 80.0 \\
\hline \multirow[t]{3}{*}{2} & Lead & 20.0 & 20.2 & 0.51 & 97.5 \\
\hline & Cadmium & 20.0 & 20.0 & 2.34 & 88.3 \\
\hline & Zinc & 20.0 & 20.5 & 3.40 & 83.4 \\
\hline \multirow[t]{3}{*}{3} & Lead & - & 15.2 & 0.4 & 97.3 \\
\hline & Cadmium & - & ND & ND & ND \\
\hline & Zinc & - & 7.1 & 1.3 & 81.2 \\
\hline
\end{tabular}

significantly diminishes the level of the studied ions in the samples.

\section{Conclusion}

This study confirms the potential of Peganum harmala seeds for removal of heavy metals from aqueous solutions. The proposed method is based on the adsorption ability of PHS toward lead, zinc and cadmium ions from aqueous solutions. Under optimized conditions with respect to the $\mathrm{pH}$ of the aqueous sample solution (4.5), time (30 $\mathrm{min}$ ) and adsorbent dosage ( $2 \mathrm{~g}$ per $45 \mathrm{ml}$ of the sample solution), the amount of the adsorbed lead, cadmium and zinc ions was 95,90 and $75 \%$, respectively, at $20^{\circ} \mathrm{C}$. A quantitative desorption of the adsorbed ions can be achieved by using diluted hydrochloric and nitric acids. It is found that the process obeys well the pseudo-second-order kinetics models and the isotherms can be well defined by Freundlich (for lead) and Langmuir (for zinc and cadmium) models.

Acknowledgments Dr. M. Movahedi Fazel, assistant professor of the Department of Plant Pathology, Faculty of Agriculture, University of Zanjan is profoundly acknowledged for his helpful discussions. The authors express their sincere gratitude to the Industrial Parks Co. 
(Zanjan) in Iran, for the financial supports (grant number 8/270) of this study. The authors gratefully acknowledge Mehdi Davari, Iranian Research Organization for Science and Technology Reference Laboratory, for his contribution to this work.

\section{References}

Abdel-Ghani NT, Hefny M, El-Chaghaby GAF (2007) Removal of lead from aqueous solution using low cost abundantly available adsorbents. Int J Environ Sci Technol 4:67-73

Abo-Ghander NS, Rahman SU, Zaidi SMJ (2006) A modified electrodialytic cell to recover heavy metals from wastewater. Port Electrochim Acta 24:367-376

Agedilova MT, Turmukhambetov AZh, Schultz EE, Shakirov MM, Adekenov SM (2006) Components of the aerial part of Peganum harmala. Chem Nat Compd 42:226-227

Babel S, Kurniawan TA (2003) Low-cost adsorbent for heavy metal uptake from contaminated water: a review. J Hazard Mater B97:219-243

Bailey ES, Olin TJ, Bricka RM, Adrian DD (1999) A review of potentially low cost sorbents for heavy metals. Water Res 33:2469-2479

Bakalár T, Búgel M, Gajdošová L (2009) Heavy metal removal using reverse osmosis. Acta Mont Slov 14:250-253

Canet L, Ilpide M, Seta P (2002) Efficient facilitated transport of lead, cadmium, zinc and silver across a flat sheet-supported liquid membrane mediated by lasalocida. Sep Sci Technol 37:18511860

Casagrande JC, Mouta ER, Soares MR (2009) Adsorption edge study about cadmium, copper, nickel and zinc adsorption by variable charge soils. Geophysical Research Abstracts, 11, EGU20099628

Dean JA (1995) Analytical chemistry handbook. McGraw-Hill, New York

Dela Rosa G, Renel-Avila HE, Bonilla-Petriciolet A, Cano-Rodríguez I, Valasco-Samos C, Martínez-ernández AL (2008) Recycling poultry feathers for $\mathrm{Pb}$ removal from wastewater: kinetic and equilibrium studies. Int J Chem Biol Eng 4:185-193

Esalah J, Husein MM (2008) Removal of heavy metals from aqueous solution by precipitation-filtration using novel organo-phosphorus ligands. Sep Purif Technol 43:3461-3475

Fenglian F, Qi W (2011) Removal of heavy metal ions from wastewaters: a review. J Environ Manag 92:407-418

Hami M, Fathi SAM, Yaftian MR, Noushiranzadeh N (2010) Solid phase extraction of copper(II) ions using C18-silica disks modified by oxime ligands. J Hazard Mater 179:289-294

Ho YS, Ofomaja AE (2006) Pseudo second-order model for lead ion sorption from aqueous solution onto palm kernel fiber. J Hazard Mater B129:137-142

Igwe JC, Abia AA (2006) Review: a bioseparation process for removing heavy metals from wastewater using biosorbents. Afr J Biotechnol 5:1167-1179

Jiang H, Xu Y, Zhang J, Zhang L, Han R (2007) Pseudo second order kinetic model for the biosorption of lead on to waste yeast: a comparison of linear and nonlinear methods and error analysis. Life Sci J 4:42-45

Kiefer R, Höll WH (2001) Sorption of heavy metals onto selective ion-exchange resins with aminophosphonate functional groups. Ind Eng Chem Res 40:4570-4576
Lanphear BP et al (2005) Low-level environmental lead exposure and children's intellectual function: an international pooled analysis. Environ Health Perspect 117:894-899

Lewis J, viewed (1 February 2007) Lead poisoning: a historical perspective. EPA J., May 1985. http://www.epa.gov/history/ topics/perspect/lead

Mehrasbi MR, Farahmandkia Z, Taghibeigloo B, Taromi A (2009) Adsorption of lead and cadmium from aqueous solution by using almond shells. Water Air Soil Pollut 199:343-351

Mohan D, Pittman CU Jr (2007) Arsenic removal from water/ wastewater using adsorbents - a critical review. J Hazard Mater $142: 1-53$

Nameni M, Alavi Moghadam MR, Arami M (2008) Adsorption of hexavalent chromium from aqueous solutions by wheat bran. Int J Environ Sci Technol 5:161-168

Oyaro N, Juddy O, Murago ENM, Gitonga E (2007) The contents of $\mathrm{Pb}, \mathrm{Cu}, \mathrm{Zn}$ and $\mathrm{Cd}$ in meat in Nairobi, Kenya. Int $\mathrm{J}$ Food Agric Environ 5:119-121

Parinejad M, Yaftian MR (2007) A study on removal of chromium(VI) oxanions from acid solutions by using oxonium ioncrown ether complexes as mobile carrier agents. Iran J Chem Eng 26:19-22

Pimentel PM, González G, Melo MFA, Melo DMA, Silva CN Jr, Assunção ALC (2007) Removal of lead ions from aqueous solution by retorted shale. Sep Purif Technol 56:348-353

Pulpati H, Biradar YS, Raiani M (2006) High-performance thin layer chromatography densitometric method for the quantification of harmine, harmaline, vasicine, and vasicinone in Peganum harmala. J AOAC Int 91:1179-1185

Santhi T, Manonmani S, Smitha T, Mahalakshmi K (2009) Adsorption of malachite green from aqueous solution onto a waste aqua cultural shell powders (Prawan waste): kinetic study. Rassayan J Chem 2:813-824

Skwarek E, Matyasek-Nawrocka M, Janusz W, Ijich Zarko V, Gunko $\mathrm{VM}$ (2008) Adsorption of heavy metal ions at the $\mathrm{Al}_{2} \mathrm{O}_{3}-\mathrm{SiO}_{2} /$ $\mathrm{NaClO}_{4}$ electrolyte interface. Physicochem Probl Min Process 42:153-164

Souag R, Touaibia D, Benayada B, Boucenna A (2009) Adsorption of heavy $(\mathrm{Cd}, \mathrm{Zn}$, and $\mathrm{Pb})$ from water using Keratin powder prepared from Algerien sheep hoofs. Eur J Sci Res 35: 416-425

Srisuwan G, Thongchai P (2002) Removal of heavy metals from electroplating wastewater by membrane. Songklanakarin J Sci Technol 24:965-976

Sud D, Mahajan G, Kaur MP (2008) Agricultural waste material as potential adsorbent for sequestering heavy metal ions from aqueous solutions-a review. Bioresour Technol 99:60176027

Vadivelan V, Kumar KV (2005) Equilibrium, kinetics, mechanism and process design for the sorption of methylene blue on to rice husk. J Colloid Interface Sci 286:90-100

Wan Ngah WS, Hanafiah MAKM (2008) Removal of heavy metal ions from wastewater by chemically modified plant wastes as adsorbents: a review. Bioresour Technol 99:39353948

Wan Ngah WS, Teong LC, Hanafiah MAKM (2011) Adsorption of dyes and heavy metal ions by chitosan composites: a review. Carbohydr Polym 83:1446-1456

Wan MW, Kan CC, Rogel BD, Lourdes M, Dalida P (2010) Adsorption of copper(II) and lead(II) ions from aqueous solution on chitosan-coated sand. Carbohydr Polym 80:891-899 
Yaftian MR, Zamani AA, Parinejad M, Shams E (2005) Ion-pair extraction of cadmium complex anions from hydrochloric acid media using oxonium ion-dicyclohexyl-18-crown-6 complex. Sep Purif Technol 42:175-180

Yaftian MR, Parinejad M, Matt D (2007) A lead-selective membrane based upon a phosphorylated hexahomotroxacalix[3]arene. J Chin Chem Soc 54:1535-1542
Zamani AA, Zarabadi AS, Yaftian MR (2009) Water soluble crown ethers: selective masking agents for improving extractionseparation of zinc and lead action. J Incl Phenom Macrocycl Chem 63:327-334

Zvinowanda CM, Okonkwo JO, Agyei N, Staden MV, Jordaan WW, Kharebe BV (2010) Recovery of lead(II) from aqueous solutions by Zea mays tassel biosorption. Am J Biochem Biotechnol 6:1-10 